\title{
Adverse Environmental Effects of Tourism on Communities in the Ecuadorian Highlands Region
}

\author{
Lourdes Ruiz \\ UIDE Universidad Internacional del Ecuador, Quito, Ecuador \\ Email: 1ruiz@internacional.edu.ec
}

How to cite this paper: Ruiz, L. (2017). Adverse Environmental Effects of Tourism on Communities in the Ecuadorian Highlands Region. Current Urban Studies, 5, 348-355.

https://doi.org/10.4236/cus.2017.53019

Received: July 7, 2017

Accepted: August 29, 2017

Published: September 1, 2017

Copyright $\odot 2017$ by author and Scientific Research Publishing Inc. This work is licensed under the Creative Commons Attribution International License (CC BY 4.0).

http://creativecommons.org/licenses/by/4.0/ (c) (i) Open Access

\begin{abstract}
The objective of this study is to determine the adverse environmental effects of tourism activities on various heritage populations located in the sierra or Andean highlands region of Ecuador. The effects being studied have been classified into impacts on the physical, abiotic, biotic, socio-culture and economic environment. The automated method using RIAM (Rapid Impact Assessment Matrix) software was employed in this analysis, which required the preparation of a baseline study in the small communities evaluated. A social perception survey was conducted of local residents regarding tourism, assisted by International University of Ecuador students fulfilling practical coursework requirements. Based on the conclusions of the case studies, some strategic proposals and recommendations were developed that can be incorporated into sustainable tourism management plans in communities with natural and cultural heritage values.
\end{abstract}

\section{Keywords}

Environmental, Cities, Tourism, Heritage

\section{Introduction}

Tourism is an engine of the economy for historic towns, as long as it is practiced with a focus on sustainability, respect for autochthonous culture, the environment and the tangible and intangible socio-cultural heritage. Sustainability implies a rational relationship between man and nature; alterations that affect the natural environment impose limits that must be evaluated before they create disturbances in that environment (Ruiz \& Garcia, 2014).

Contemporary thinking on sustainable tourism has largely focused on reducing 
the impacts of tourism while maximizing benefits to sustain local communities, thus promoting inter- and intra-generational equity. Sustainable tourism can be enhanced by mobile connectivity through new space-time practices and using ephemeral interpersonal relationships to harness niche groups to create bottomup social systems interested in sharing experiences, ideas and resources (Dickinson, Filimonau, Hibbert, Cherrett, Davies, Norgate, \& Winstanley, 2017).

The United Nations has deemed 2017 to be the year of Sustainable Tourism for Development (UNWTO, 2015). The UNWTO Secretary General Taleb Rifai describes 2017 as "a unique opportunity to advance the contribution of the tourism sector to the three pillars of sustainability-economic, social and environment-while raising awareness of the true dimensions of a sector which is often undervalued" (UNWTO, 2015, cited by Bramwell, Higham, Lane, \& Miller, 2017). Integration is an important concept that helps addressing complex social-environmental problems (Tengberg \& Valencia, 2017).

Effective environmental policies and programmers need to be informed by a comprehensive understanding of the biophysical, social and economic processes of a system, their complex interactions, and how they respond to different changes (Kelly et al., 2013). In other words, "understanding a complex whole requires knowledge about specific variables and how their component parts are related" (Ostrom, 2009).

The county with the most emphasis placed on sustainable tourism within their plan was found to have the highest performance evaluations (Boley, McGehee, \& Hammett, 2017). In this idea, the local environmental impacts of communities dedicated to tourism can cause undesirable effects on the host environment of a given area, and contribute to its degradation over time. The regional level has been recognized as a good scale for implementing actions towards sustainable development (Wang, Sun, Wang, \& Lou, 2014).

The communities located within the Ecuadorian Andean region, known as the sierra region, are the most visited places in the entire country due to the enormous natural and cultural diversity they offer, which includes various ecosystems, such as paramus or high-altitude plateaus, could forests, lakes, active volcanos, hot springs, archeological sites, indigenous communities, towns and villages of varying sizes and colonial haciendas. Historical communities in the Ecuadorian highlands region that are rich in natural and cultural heritage are currently a subject of heightened interest (Andrade, 2007).

The case studies were done in three communities that are similar in size and in their status as tourism destinations, within the geographic territory of the sierra region of Ecuador:

- Baños de Agua Santa is one of the nine cantons of the province of Tungurahua, which is located in the central Andean region of Ecuador, and is the smallest and most densely populated province in the country. Thanks to its strategic location, its linkages to the commercial dynamics of the two main economic poles of the country and the entrepreneurial spirit of its people, as 
well as a number of local participatory management initiatives, it has become an "atypical” example of development in the country's central region (Velasco et al., 2015; Ospina, 2011; Censo de Población y Vivienda, 2010).

- Mindo, Pichincha province is a small rural parish in San Miguel de los Bancos. It is located in a valley next to the Mindo-Nambillo Protective Forest, and offers community tourism, adventure tourism including extreme sports, and nature tourism featuring the biodiversity and unique and beautiful landscapes. It is visited by both national and international tourists, helped in part by its proximity to Quito (Pichincha province). It has been the focus of environmental conflicts stemming from the construction of the heavy crude oil pipeline (Sierra, Tello, \& Trujillo, 2015; Andrade, 2007; Censo de Población y Vivienda, 2010).

- Papallacta, a parish within Napo province, is part of the eastern range of the Andes. Its main tourist attraction are its thermal baths and hot springs, and sports fishing is done at the nearby lake, with large aquifer reserves which supply water to Quito, the capital of Ecuador (Manchego and Ordoñez, 2015; Censo de Población y Vivienda, 2010).

\section{Methodology}

A systemic-structural method is being used here, since a study of environmental impacts encompasses all of the dimensions of sustainable development based on a systematic and holistic approach. The assessment makes it possible to evaluate the potential impacts (Gutierrez, 2016). The characteristics of environmental impacts are expressed through different environmental impact assessment methodologies, focused on different attributes, such as: their nature, connotation, magnitude, significance, synergy, scope, and reversibility (Gutierrez, 2015a; Ruiz, 2015).

The environmental impact assessment was conducted using the automated method of the RIAM software, which required preparing a baseline study of the environment in similar heritage communities located in the geographic area of the sierra (Andean highlands) region of Ecuador (Velasco et al., 2015; Sierra, Tello y Trujillo, 2015; Manchego y Ordoñez, 2015).

The mathematical evaluation criteria used by the RIAM method must be defined for independent and dependent variables, and are based on intervening variables that can be conditioned by a change in the place or location of the individual projects (Pastakia, 1998).

Environmental assessments are often carried out using matrix-based methods in which one dimension of the matrix is "Impacting Factors" (F) and the other is the "Environmental Components" (EC) which are affected by the impacting factors (Namin et al., 2014).

Evaluating environmental impacts involves assigning a concrete (objective measurement) or abstract value (subjective measurement) to the environmental impacts, to establish a critical qualitative or quantitative assessment. This is 
based on identifying variables and indicators, and establishing and measuring valuation criteria. It is based on identifying variables and indicators, and measuring and making judgments in assigning values. The values obtained can generally be expressed in terms of relevance, priority, or magnitude (Gutierrez, 2015b).

According to Gomez and Gomez (2013), environmental significance interpreted in terms of human health and welfare, is what defines environmental impact. Other authors (Sadler, 2003; Ruiz, 2000), propose that environmental impact is the direct and indirect consequences of a beneficial (positive) or adverse (negative) nature, which are produced by humans to natural and socio-economic systems on which their well-being depends, as the result of an environmental change caused by an action or set of actions of natural or anthropic origins. Ruiz (2016) argues that public works, such as the construction of a highway, a city, an industry, recreational areas or any similar activity has an impact on the environment.

The RIAM methodology was employed based on various exercises and practical course-related work done by students of the Tourism and Hospitality School of the UIDE, at the Quito main campus. The three case studies were done in the Ecuadorian highlands region:

- Town of Baños de Agua Santa

- Town of Mindo,

- Town of Papallacta.

The criteria used in this research to determine the impacts the occur as the result of a strategy of tourism development in a town or of a program to project and plan the tourism infrastructure in heritage sites must take into account the area that can be affected by these tourism interventions. The study looked at the social perception that local residents have of tourism through semi-structured interviews with local subjects, in order to gauge their perceptions of tourism in their community (Covarrubias and Conde, 2009).

The assessments are linked to four environmental components or dimensions of sustainability, according to the guidelines for analyzing the physical and socioeconomic environment described in a simplified teacher's guide to baseline studies (Table 1), and they are grouped into the following categories: physicalchemical, biological-ecological, socio-cultural and economic-operational.

The components to be evaluated have been assigned grades of adverse effects ranging from $-\mathrm{A},-\mathrm{B},-\mathrm{C}$ to $-\mathrm{D}$, with $-\mathrm{D}$ the most negative value; while a zero grade means that the assessment does not apply to that component.

\section{Results and Discussion}

For each of the three communities evaluated, different results were obtained for some variables while similarities were found for others, as evidenced in Table 2.

The results of the samples of the three communities with significant tourism activity in the Ecuadorian sierra reveal some similarities in the physical-chemical 
Table 1. Simplified guide for environmental baseline studies.

\begin{tabular}{|c|c|c|}
\hline $\begin{array}{l}\text { Environmental } \\
\text { component }\end{array}$ & Aspects & Description of the aspects to evaluate \\
\hline \multirow{7}{*}{ Physical-chemical } & $\begin{array}{l}\text { Geology and } \\
\text { Geomorphology }\end{array}$ & $\begin{array}{l}\text { Types of rocks. Geotechnical characteristics and } \\
\text { mineral deposits. Relief, contour and slope analysis. }\end{array}$ \\
\hline & Soil & Characterization of soils. Potential uses. \\
\hline & $\begin{array}{l}\text { Seismic } \\
\text { conditions }\end{array}$ & $\begin{array}{l}\text { Seismic-tectonic survey, seismic hazards in the re- } \\
\text { gion. Construction alternatives for the project. }\end{array}$ \\
\hline & Air quality & $\begin{array}{l}\text { Possible emissions caused by the project. Health } \\
\text { protection areas. Continuous and occasional } \\
\text { (peak) noise levels. Emissions of particulates } \\
\text { and greenhouse gases. }\end{array}$ \\
\hline & Climate & $\begin{array}{l}\text { Microclimate, air quality and the influence } \\
\text { of the project. } \\
\text { Temperature, winds, humidity, precipitation, } \\
\text { sun exposure, evapotranspiration. }\end{array}$ \\
\hline & Fresh water & $\begin{array}{l}\text { Availability, management and quality of public } \\
\text { water supply services. Sources of supply. Surface } \\
\text { and underground water and their quality. } \\
\text { Natural and artificial drainage systems. } \\
\text { Sources of contamination. }\end{array}$ \\
\hline & Salt water & $\begin{array}{l}\text { Quality of coastal and marine waters. Currents, } \\
\text { tides and sources of contamination. }\end{array}$ \\
\hline \multirow{3}{*}{ Biological-ecological } & $\begin{array}{l}\text { Vegetation } \\
\text { and flora }\end{array}$ & $\begin{array}{l}\text { Land-based, aquatic and marine plant types and } \\
\text { formations. Endemic species, species in danger } \\
\text { of extinction. Fragile or highly vulnerable } \\
\text { ecosystems. Forests. Urban green areas. }\end{array}$ \\
\hline & $\begin{array}{c}\text { Animal } \\
\text { life (fauna) }\end{array}$ & $\begin{array}{l}\text { Status and distribution of land, aquatic and } \\
\text { marine animal life. Endemic species and } \\
\text { endangered species. Habitat, ecosystems, } \\
\text { migration patterns. Fisheries and wildlife. }\end{array}$ \\
\hline & $\begin{array}{l}\text { Ecological } \\
\text { relationships }\end{array}$ & $\begin{array}{l}\text { Management of protected areas and areas of } \\
\text { high environmental sensitivity. } \\
\text { Relationships: climate-vegetation-soil; } \\
\text { climate-topography-vegetation. }\end{array}$ \\
\hline \multirow{2}{*}{ Socio-cultural context } & $\begin{array}{l}\text { Human } \\
\text { settlements } \\
\text { and social actors }\end{array}$ & $\begin{array}{l}\text { Populated settlements and key social stakeholders. } \\
\text { Social behaviors and poverty. Total resident } \\
\text { and occasional population, by ages and sex. } \\
\text { Labor force. Education and health. }\end{array}$ \\
\hline & $\begin{array}{l}\text { Cultural } \\
\text { heritage } \\
\text { and recreation. }\end{array}$ & $\begin{array}{l}\text { Historical and cultural traditions. Tangible } \\
\text { and intangible heritage of a historical and } \\
\text { archeological value, monuments and } \\
\text { architectural works. Recreation. }\end{array}$ \\
\hline \multirow{2}{*}{$\begin{array}{l}\text { Economic-operational } \\
\text { environment }\end{array}$} & $\begin{array}{l}\text { Economic } \\
\text { relations }\end{array}$ & $\begin{array}{l}\text { Types of property and ownership patterns } \\
\text { by sectors. Average incomes and livelihoods. }\end{array}$ \\
\hline & Services & $\begin{array}{l}\text { Basic services available to the community } \\
\text { and the quality of those services. Infrastructure. }\end{array}$ \\
\hline
\end{tabular}


Table 2. Results of the application of RIAM in three selected communities.

\begin{tabular}{ccccc}
\hline \multirow{2}{*}{$\begin{array}{c}\text { Communities } \\
\text { assessed }\end{array}$} & \multicolumn{4}{c}{ Environmental components } \\
\cline { 2 - 5 } & Physical-chemical & Biological-ecological & Socio-cultural & Economic-operational \\
\hline Baños de & - C & $-B$ & $-C$ & 0 \\
Agua Santa & - C & $-B$ & $-D$ & 0 \\
Mindo & - C & $-B$ & $-A$ & 0 \\
Papallacta & & &
\end{tabular}

components of the adverse impacts that have taken place, especially due to the excessive overexploitation and deterioration in the quality of fresh water, soil quality due to land use changes and agricultural and livestock activities, and air quality from vehicular and noise pollution.

It was also found that there have been negative biological and ecological impacts on all of the communities, resulting from deforestation, the alteration of habitats and the introduction of exotic plant species (Velasco et al., 2015; Sierra, Tello, \& Trujillo, 2015; Manchego and Ordoñez, 2015).

The adverse impacts related to the socio-cultural component vary from town to town (Velasco et al., 2015; Sierra, Tello, \& Trujillo, 2015; Manchego \& Ordoñez, 2015). However in Papallacta,the situation was not found to be particularly negative according to interviews of local residents (Manchego y Ordoñez, 2015).

The economic impacts of tourism are reported to be positive, given the increase in employment opportunities and the improvements made to urban infrastructure in the three communities studies (Velasco et al., 2015; Sierra, Tello, \& Trujillo, 2015; Manchego and Ordoñez, 2015).

Among residents, there is an insufficient perception of the accumulated impacts of tourism and the effects of the synergies of each type of tourism that is developed, in relation to the characteristics and identity of the traditional populations. The measures proposed and existing monitoring efforts are generally weak among tourism companies. There is a deficiency in the implementation of monitoring and environmental auditing on the part of the municipal governments and other public institutions (Velasco et al., 2015; Sierra, Tello, \& Trujillo, 2015; Manchego and Ordoñez, 2015).

\section{Conclusions}

- The conclusions of the three case studies of tourism-oriented communities located in similar geographic areas of the Ecuadorian sierra provide insights that can be used to develop strategic proposals and recommendations that can be incorporated into tourism management plans in historic towns with heritage assets.

- Applying the RIAM methodology to historic communities with tourism potential was used to assess environmental impacts of a physical-chemical 
nature and impacts on biodiversity and ecosystems, and it was also a useful instrument for evaluating the socio-cultural and economic-operational impacts that have occurred and that are projected as a result of tourism-focused development in the selected case studies in different environmental contexts, projects and situations, with the aim of assessing different planning options.

- Legal, educational and regulatory instruments are not effective by themselves to create awareness and change attitudes regarding the need to protect and care for the environment, if they are not accompanied by a solid environmental culture which seeks to preserve nature and the cultural identity of local inhabitants. Efforts are needed to strengthen environmental education and outreach activities that engage all public and private organizations, institutions and the community. These efforts must include capacity-building and training programs for the communities, entrepreneurs, institutions and workers in general.

\section{References}

Andrade, M. (2007). De la serpiente tecnológica a la mariposa de las secuoyas: El proyecto OCP y la ecología política de un conflicto. Ecuador: Editorial FLACSO.

Boley, B., McGehee, N., \& Hammett, A. (2017). Importance-Performance Analysis (IPA) of Sustainable Tourism Initiatives: The Resident Perspective. Tourism Management, 58, 66-77. https://doi.org/10.1016/j.tourman.2016.10.002

Bramwell, B., Higham, J., Lane, B., \& Miller, G. (2017) Twenty-Five Years of Sustainable Tourism and the Journal of Sustainable Tourism: Looking Back and Moving Forward. Journal of Sustainable Tourism, 25, 1-9. https://doi.org/10.1080/09669582.2017.1251689

Censo de Población y Vivienda (2010). Proyecciones referenciales de población a nivel cantonal-parroquial. Ecuador: Secretaria de Planificación y Desarrollo.

Covarrubias, R., \& Conde, E. (2009). Percepción del nivel de satisfacción de los residentes con la actividad turística. Caso Comala, Colima, México. TURyDES. Revista Turismo y Desarrollo Local Sostenible, 2, No. 4. http://www.eumed.net/rev/turydes/index.html

Dickinson, J, .Filimonau, V., Hibbert, J., Cherrett, T., Davies, N., Norgate, S., \& Winstanley, C. (2017). Tourism Communities and Social Ties: The Role of Online and Offline Tourist social Networks in Building Social Capital and Sustainable Practice. Journal of Sustainable Tourism, 25, 163-180. https://doi.org/10.1080/09669582.2016.1182538

Gómez, D., \& Gómez, T. (2013). Evaluación de Impacto Ambiental. 3ra. Edición, Madrid: S.A. MUNDI-PRENSA LIBROS.

Gutiérrez, R. L. (2015a). Impact Assessment of Tourism Construction in Cuba. Journal of Building Construction and Planning Research, 3, 10-17 https://doi.org/10.4236/jbcpr.2015.31002

Gutierrez, R. L. (2015b). The Environmental Effects of Tourism Architecture on Island Ecosystem in Cayo Guillermo, Cuba. Journal of Environmental Protection, 6, 1057-1065. https://doi.org/10.4236/jep.2015.69093

Gutierrez, R. L. (2016). Environmental and Energy-Related Impacts in the Operating Cycle of Beach Hotels: Case Studies from the Canton La Libertad, Ecuador. International Journal of Advanced Engineering Research and Science, 3, 73-77. 
Kelly, B. et al. (2013). Selecting among Five Common Modelling Approaches for Integrated Environmental Assessment and Management. Environmental Modelling and Software, 47, 159-181.

http://www.sciencedirect.com/science/article/pii/S1364815213001151

Manchego, S., \& Ordoñez, M. (2015). Estudio ambiental de Papallacta. Trabajo de curso. Escuela de Gestión Turística y Medio Ambiente, Quito: Universidad Internacional del Ecuador.

Namin, F. et al. (2014) New Model for Environmental Impact Assessment of Tunneling Projects. Journal of Environmental Protection, 5, 530-550. https://doi.org/10.4236/jep.2014.56056

Ospina, P. (2011). El territorio de senderos que se bifurcan: Tungurahua; economía, sociedad y desarrollo. Quito: Universidad Andina Simón Bolívar, sede Ecuador, Corporación Editora Nacional.

Ostrom, E. (2009). A General Framework for Analyzing Sustainability of Social-Ecological Systems. Science, 325. https://doi.org/10.1126/science.1172133

Pastakia, C. (1998). The Rapid Impact Assessment Matrix (RIAM)-A New Tool for Environmental Impact Assessment. Hørsholm: VKI.

Ruiz, L, (2000). La evaluación de impacto ambiental de las construcciones turísticas en la cayería norte y otras zonas costeras de Cuba. Tesis para la obtención del grado científico de Doctor en Ciencias Técnica. La Habana: Inédito. ISPJAE.

Ruiz, L. (2015). The Effects of Tourism Architecture on Island Ecosystems. Journal of Building Construction and Planning Research, 3, 163-170.

https://doi.org/10.4236/jbcpr.2015.34016

Ruiz, L. (2016). Strategic Environmental Assessment of Towns in Ecuador with Tourism Potential. Journal of Building Construction and Planning Research, 4, 83-88. https://doi.org/10.4236/jbcpr.2016.41005

Ruiz, L., \& García, D. (2014). Análisis de la falla ambiental de las construcciones turísticas en ecosistemas costeros. Cub@: Medio Ambiente y Desarrollo. Revista electrónica de la Agencia de Medio Ambiente, 14, No. 26.

Sadler, B. (2003). Taking Stock of EA Capacity Development. In Environmental Assessment Outlook. Lincoln: Institute of Environmental Management and Assessment.

Sierra, M., Tello, M., \& Trujillo, B. (2015). Estudio ambiental de Mindo Trabajo de curso. Escuela de Gestión Turística y Medio Ambiente, Quito: Universidad Internacional del Ecuador.

Tengberg, A., \& Valencia, S. (2017). Science of Integrated Approaches to Natural Resources Management. A STAP Information Document. Washington DC: Global Environment Facility.

UNWTO (2015). United Nations Declares 2017 Year of Sustainable Tourism for Development.

http://media.unwto.org/press-release/2015-12-07/united-nations-declares-2017-interna tional-year-sustainable-tourismdevelop

Velasco, G. et al. (2015). Estudio ambiental de Baños de Aguas Santas. Trabajo de curso. Escuela de Gestión Turística y Medio Ambiente, Quito: Universidad Internacional del Ecuador.

Wang, Y. T., Sun, M. X., Wang, R. Q., \& Lou, F. (2014). Promoting Regional Sustainability by Eco Province Construction in China: A Critical Assessment. Ecological Indicators, 51, 127-138. 